\title{
Analysis of social models in Central and Eastern Europe - A focus on poverty and social exclusion
}

\author{
Ruxandra ARGATU \\ The Bucharest University of Economic Studies, Bucharest, Romania \\ argatu.ruxandra@gmail.com
}

\begin{abstract}
In the present context, defined by a variety of social changes, social advancement is a key point that needs to be sheltered and ensured both in Romania as well as at the level of the European Union, in order to have a coherent European space, to reach and maintain a high level of social and economic welfare. The improvement of the social domain can be triggered by using the principles of the European Social Model, which incorporates values and institutions specially established to protect the integrity of people who are socially disadvantaged. Thus, the paper aims, on one hand, to analyze literature review aspects of the European Social Model as being a social development one and to identify the criteria according to which progress is established in relationship with this model. On the other hand, another goal of the paper is to make a comparative analysis between Romania's performance in the context of Central and Eastern European countries' situation. The purpose of the analysis is to diagnose the progress recorded and the social area in which it took place, as well as the differences between countries. The focus of the analysis will be placed on poverty and social exclusion, as dimensions of the European Social Model. The methodology that will help in undertaking the research comprises two elements: literature review and document analysis. The literature review component involves pinpointing information obtained from scientific articles about the European Social Model and aspects associated with it, available in online databases. The second part of the methodology refers to document analysis, which supposes the assessment of reports issued by organizations that provide such statistical data (Eurostat, World Bank, Social Progress Imperative).
\end{abstract}

Keywords: European Social Model, poverty, social exclusion, Central and Eastern Europe, Romania.

\section{Introduction}

Nowadays, it is widely known that a country can have access to social and economic welfare only if it complies with certain norms and regulations, be them either formal (laws, regulations, policies) or informal ones. However, according to Leoni (2016), social changes are a considerable impediment in the application of social strategies, whereas Scharpf (2002) claims that the differences triggered by the unique legal and institutional profile of each European state hinder the implementation of social protection policies that are meant to foster the social wellbeing of individuals.

Taking these aspects to a smaller spatial framework and displaying them at the level of the European Union, Kastoryano (2006) states that Europe is a sum of institutions whose role is to urge countries to comply with certain norms and principles. Nevertheless, the scope of these regulations is to maintain the security and stability of the European space. In addition, Reianu and Nistor (2017) have a similar opinion concerning this aspect, specifying that the establishment of the European Union was aimed towards nurturing values like democracy, welfare as well as a strong consolidation and merging between its member states. Furthermore, another goal of the European Union is the minimization of the economic disproportions that take place both at the member states' level as well as at the interregional level. 
As per Sage (2013), social and economic inequalities are also to be considered among the causes that trigger imbalances in a nation's social domain, an example that could be taken in consideration in this sense being the income inequalities, which block the unity and cohesion of a country.

In the turbulent context of the continuous economic and social changes (Cantaragiu et al., 2014) and challenges that occurred throughout time within the EU, a strong need for the creation of a standard framework of promoting social welfare appeared. Thus, one such representative example of structure intended to promote the unity of European societies is the European Social Model, whose theoretical framework will be illustrated in the literature review part.

The subject discussed in the paper is particularly important because the most valuable asset of a country is represented by the human one, meaning its inhabitants. Furthermore, without constantly investing in this asset through social policies, a country cannot advance and obtain a competitive advantage, in a world in which change is the key point of action.

The article aims to depict theoretical aspects regarding the model, through a literature review approach, and further on to assess the situation of two of its components, poverty and social exclusion, in Central and Eastern Europe, based on an analysis of reports written by legislative and social institutions at the level of the European Union. The research objectives are to determine the evolution of poverty and social exclusion indicators in Central and Eastern Europe in the period 2014-2017 and to display Romania's social performance within this block of countries.

\section{Literature review}

\section{The European Social Model - conceptual approach and typologies}

According to Timofei (2011) the establishment of the European Union and further on its development was based on core principles of European integration such as the elimination of trade barriers in order to reach economic cohesiveness, at the stage of free trade agreement. Thus, it can be noticed that the main priority was the sheltering of the economic stability, while social issues were not taken into consideration to such a great extent.

Later on, the economic and monetary union opened the gate to the valuation of social aspects at their real level of significance and in the present, both economic and social issues are tackled in the European Union as interdependent elements, to obtain a welldeveloped European territory and identity.

The European Commission defines the European Social Model as being an entirety of principles such as the defense of individuals' freedom, the offering of a fair and equal treatment to citizens in terms of social sheltering and caretaking disadvantaged social groups (European Commission in Timofei, 2011, p.12). Timofei (2011) acknowledges that the model implies the following features: the protection of employees' rights, namely providing appropriate working conditions and an egalitarian treatment; social defense policies; procedures specifying the threshold of the work time and the employees' health protection; the commitment of the government to ensure the employment of individuals. Moreover, the author states that these measures have as an end goal the cancellation of poverty and making sure that citizens are given access to proper standards of living. Püss et 
al. (2010) use a similar perspective and support the previous point of view, stating that the European Social Model is an approach which merges continuous economic improvements with living and labor aspects.

According to Szyjko (2011) the countries which are part of the European Union have in common a certain perspective regarding the way in which society has to be managed, this being referred to in the present as the European Social Model. At the moment, Europe is divided through the usage of different social models, each one of them having its own particularities, which developed based on certain criteria (Crouch, Traxler et. al., ScharpfSchmidt, Ferrera et. al. in Szyjko, 2011, p.87): eligibility and coverage of risks, benefit structure, financing ways, intensity of services, family policy, employment norms, governance, industrial relationships.

Szyjko (2011) underlines the particularities of each European model, thus outlining the individual character that these four models present: Anglo Saxon model (specific to UK, Ireland, US and Canada; the state directs the social strategies; liberal approach), Continental model (corresponds to Germany, France, Belgium and Netherlands; the inhabitants' social wellbeing is safeguarded through contributions attached to the wages; conservative approach), Nordic model (specific to Scandinavian countries; the social protection sector is supported by taxes; social democratic), Mediterranean model (strict policies of labor defense).

\section{Poverty and social exclusion}

The two social issues approached in the paper have been the center of thorough research studies, due to their profoundly disturbing impact that they have over maintaining the social stability of a country. Across time, many authors have attempted to understand the two concepts and to find the most appropriate indicators for quantifying their effects.

In this sense, Madanipour et al. (2015) states that there are no clear demarcation points in between poverty and social exclusion, from the conceptual point of view, and that their understanding in time has rendered distinct outputs. The motivation that stands behind this fact is given by the approach used by the authors who have studied these phenomena, since a part of them insisted that they should be analyzed separately whereas other researchers have carried out their inquiries by linking them in a singular notion.

In what concerns poverty, Akindola (2009) acknowledges that it is a concept which is directed by many variables, a person's income being just one of them, therefore a single definition cannot be formulated As a consequence, elaborating action plans for fighting against poverty is a tricky task, since the manner in which people undergo and interpret poverty is a dissimilar one. The author states that the basic meaning of poverty was associated for a long period of time with the economic deprivation of individuals (Strat and Stefan, 2017), or in other words, with the absence of buying power. According to Sarlo and Ross et al. (in Akindola, 2009,p.123) poverty supposes the lack of economic supplies that would help an individual fulfill basic needs such as nutrition and housing, that are further critical for obtaining bodily comfort.

Akindola (2009) further argues that deprivation should not be understood and measured only from the economic point of view, knowing the fact that there are also other causes that contribute to its development. If only the economic aspects were considered, 
the chances of creating appropriate, close to reality strategies in diminishing the phenomenon would be minimal. Palmer (2011) supports this point of view and demonstrates, based on previous studies, that besides the economic approach, there are other two distinct approaches in conceptualizing it: the basic needs perspective and the capability viewpoint.

The basic needs perspective supposes that a person is found in the inability of accomplishing basic life conditions, starting from nourishment, water and shelter and reaching to schooling and knowledge. The reason for which this approach took shape is given by the differences in the welfare indicators chosen by countries, which further led to the urge of creating a more comprehensive facet for displaying prosperity.

Conversely, the capability perspective implies the ability of an individual to transform the implying needs in welfare and it is in a strong connection with that person's distinguishing attributes, meaning age and gender as well as with extraneous variables that cannot be controlled by the individual (the facilities that the person has access to and the neighboring context).

Oxfam (in Misturelli and Heffernan, 2010, p.40) strengthens the previous points of view and underlines that poverty can be comprehended and connected either to deprivation or to the absence of an element that is of an utmost importance for an individual.

Akindola (2009) emphasizes that poverty can manifest itself either absolutely or relatively. Absolute poverty supposes living underneath the existence standards that are recognized by society, or from another angle, it can be viewed as the situation in which an individual's income is insufficient in fulfilling minimal needs. This type of poverty affects developing countries, since a large share of people do not have the chance of accessing resources like food, water, health and educational services and other social facilities. On the other hand, relative poverty occurs when the level of material comfort experienced by a household is situated below the one considered as ordinary by society and it is specific to developed countries.

Concerning the measurement of poverty, Bodea and Herman (2014) state, on the basis of preceding research, that poverty can be measured through the help of the following indicators: poverty headcount ratio, rate of poverty, Gini coefficient and other indicators that concern living aspects such as the access to water, durable goods ownership, education and spending undertaken for consumption purposes. Oppositely, Copus et al. (2015) affirm that another measure of quantifying poverty is the at-risk-of-poverty rate, used by the European Union when establishing the efficiency of poverty reduction goals specified in the EU 2020 strategy. More precisely, the at-risk-of-poverty rate displays the percentage of individuals who belong to households in which the available income is under the threshold of $60 \%$ computed with reference to the national median. The authors specify that the difficulty in interpreting the results of the indicator is given by the point of reference that establishes the necessary $60 \%$ from the median.

Regarding social exclusion, Peace (2001) asserts that this phenomenon can be comprehended from 2 perspectives: restricted and extensive. The restrictive approach defines social exclusion in correlation with monetary poverty, thus it refers to the individuals who are employed without payment and to the ones who are remunerated with 
low salaries. Thus, this viewpoint is connected with the principle of social interrelatedness, according to which the unity of a society is safeguarded by the involvement in the paid labor force. Conversely, the extensive approach goes beyond poverty or other forms of deprivation and it is a tangled network of multiple variables, such as non-recognition of individual social privileges and absence of living facilities. These components further produce negative effects, as they lead to family disruptions, alteration of social interconnections as well as the disappearance of the individuality and significance of a person. Jehoel-Gijsbers (2007) supports the above point of view, stating that social exclusion is seen in the present as a mixture of material dispossession, a minimal social involvement and standardizing homogenization.

According to Păunescu (2014), efforts towards reducing the troublesome effects of poverty and other types of social inequalities are facilitated by social innovation. The concept of social innovation has presented a high interest for researchers in the latest decade, given the burden of negative social changes. Furthermore, it involves different categories of participants (the government, public institutions, companies, citizens) and it aims to enhance social prosperity and produce value, through imaginative resolutions. Social innovation appears whenever there are contrasts between the existing and the wished state of facts and it can resolve issues either for a smaller audience (at the company level) or a larger public (macroeconomic imbalances). The efficiency of social innovation strongly depends on social capital, which, as stated by Păunescu and Badea (2014), refers to the valuable resources held by an individual through his social connections: abilities, expertise, cognition and resources. In addition, social capital can be formed at different layers, from people to the organizational level and finally to the entire society.

\section{Methodology}

The research method employed in the paper and used to validate the initial study hypotheses is document analysis, which involves the assessment of reports and statistical data elaborated by European Union institutions and that tackle poverty and social exclusion. The evaluation will involve the Central and Eastern European (CEE) countries: Poland, Czech Republic, Slovakia, Slovenia, Hungary, Romania, Bulgaria and Croatia, while the time frame involved is 2014-2017. Furthermore, the basis of the analysis is given by poverty and social exclusion indicators, such as real GDP growth, at-risk-of-poverty-rate (in $\%)$, the share of people at risk of poverty and social exclusion (\%), the Social Progress Index dimensions (basic human needs, foundations of wellbeing, opportunity). The data sources employed were Eurostat, World Bank and Social Progress Imperative, while the research instrument used for data processing was Microsoft Excel.

\section{Results and discussions}

In what concerns the economic framework, Table 1 highlights the fact that year 2014 was characterized by subtle but steady growth for Central and Eastern Europe, explained by a flourishing demand. As it can be observed from the table below, constant growth rates took place mostly in Romania, Poland and Slovakia. However, Czech Republic did not manage to improve its situation as it recorded a small growth, moving from a negative value, in 2014, to a positive one in 2015 , the country being presumed to find itself in a state of recession for 
6 years in a row, since 2008. Social aspects that could be added to the economic ones are high values of unemployment among the young people segment and demographic ageing. The World Bank (2014) also underlines the correlation between unemployment and demographic ageing, thus the countries that face high unemployment of the young individuals are also confronted with population downfalls.

Table 1. Real GDP growth (\%) in Central and Eastern Europe

\begin{tabular}{|l|l|l|l|}
\hline \multicolumn{1}{|c|}{$\begin{array}{c}\text { Real GDP growth } \\
\text { (percent) }\end{array}$} & $\mathbf{2 0 1 3}$ & $\mathbf{2 0 1 4}$ & $\mathbf{2 0 1 5}$ \\
\hline EU11 & 1.4 & 2.6 & 3.0 \\
\hline Bulgaria & 0.9 & 1.7 & 2.4 \\
\hline Croatia & -1.0 & -0.5 & 1.2 \\
\hline Czech Republic & -0.9 & 2.0 & 2.4 \\
\hline Estonia & 0.8 & 2.0 & 3.0 \\
\hline Latvia & 4.1 & 3.8 & 4.0 \\
\hline Lithuania & 3.3 & 3.3 & 4.0 \\
\hline Hungary & 1.1 & 2.4 & 2.5 \\
\hline Poland & 1.6 & 3.3 & 3.5 \\
\hline Romania & 3.5 & 2.8 & 3.2 \\
\hline Slovenia & -1.1 & 0.6 & 1.3 \\
\hline Slovak Republic & 0.9 & 2.2 & 3.1 \\
\hline memo: & & & \\
\hline Euro Area & -0.4 & 1.1 & 1.5 \\
\hline
\end{tabular}

However, the evolution of GDP is not an efficient sole measure for assessing the social welfare level of a country therefore other relevant indicators must be analyzed. As stated in the literature review section, poverty can be approached from multiple perspectives. One of them is the economic point of view, in this case the most relevant indicator being income, starting from which other derivate measurement tools appeared (e.g. at-risk-of-poverty rate), while a second approach is the material point of view, which supposes people's access to resources and facilities that enable a decent living. In addition, according to Eurostat (2016a), the European Union intends to fight against poverty by taking 20 million persons out of this risk until 2020, through the Europe 2020 strategy.

From the first perspective, the monetary poverty and its associated indicator, the at-risk-of-poverty rate, Eurostat (2016b) specifies that in 2015, 1 out of 4 individuals $(23,7 \%)$ at the level of the European Union were at risk of poverty or social exclusion. Further on, 38,4 million people from this percentage faced multiple facets of poverty, the most predominant of them being the relative monetary poverty, that leaves its trace upon $10,2 \%$ of the EU inhabitants.

Concerning the magnitude of the phenomenon in CEE, Figure 1 illustrates that Romania was the leader in what concerns the at risk of poverty rate, registering $25,4 \%$ meaning that $25,4 \%$ of the population is associated to households whose income is situated under $60 \%$ from the national median. The value is a critical one, since the EU average was well below 20\%, but another EU member state confronting with serious poverty was Serbia, whose share was equal with the one of Romania. 
The CEE country with the lowest share of people at risk of poverty was Czech Republic (9,7\%), whereas other minimal values belonged to Netherlands $(11,6 \%)$ and Norway $(11,9 \%)$.

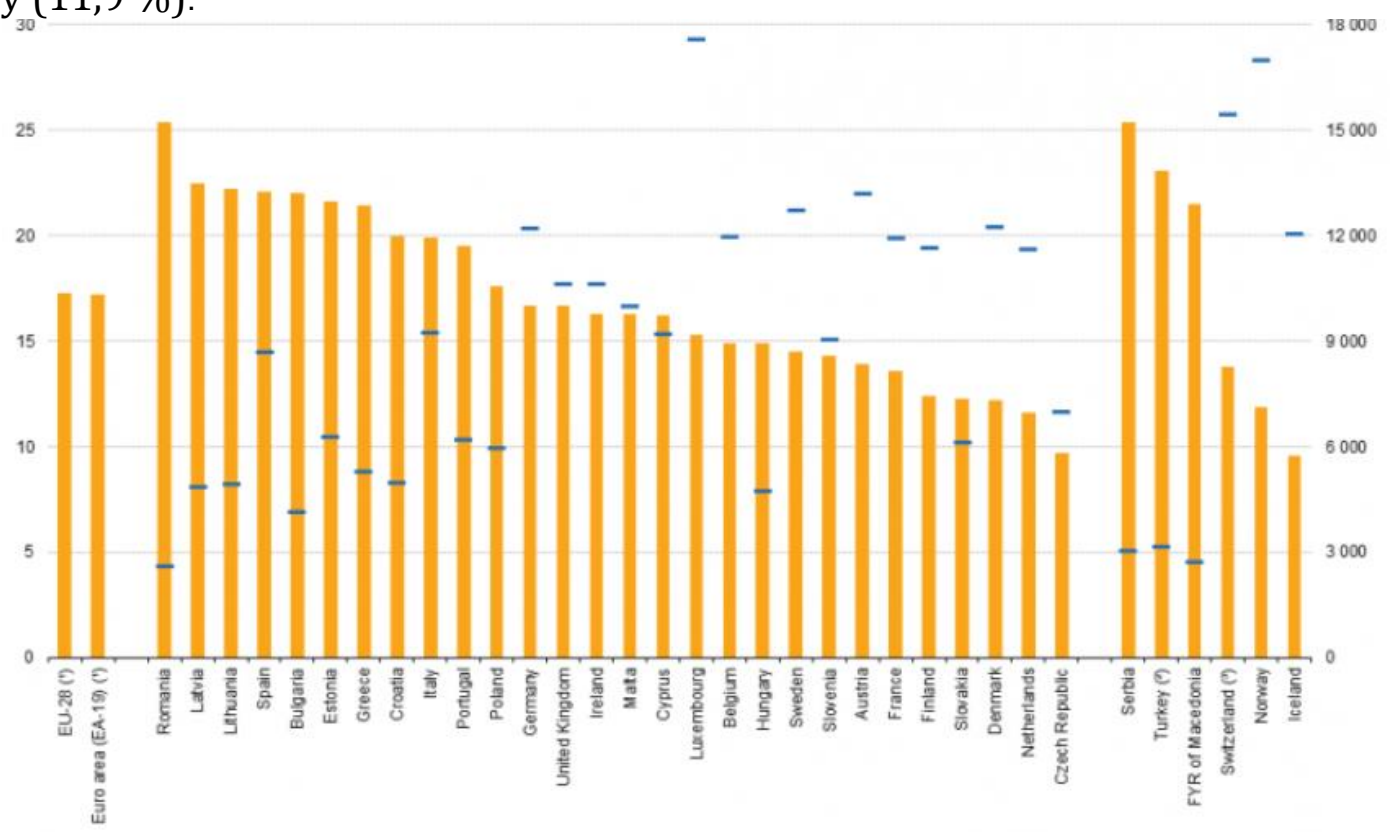

PICBE | 86

= At-risk-of poverty rate (\$) (left-hand axis)

-At-risk-of-poverty threshold (PPS) (riaht-hand axis)

Figure 1. At risk of poverty rate (\%) - year 2015

Source: Eurostat, 2017a.

Approaching the issue based on the number of persons at risk of poverty or social exclusion in 2015, by age group, Table 2 indicates that for the age group $0-17$, the highest value was obtained by Romania (46,8\%) and the lowest belongs to Slovenia $(16,6 \%)$. In the case of adults, Bulgaria scored the highest $(37,5 \%)$ and Czech Republic the lowest (13,6 \%). Finally, the elderly are strongly socially disadvantaged in Bulgaria (51,8\%) and less in Czech Republic (10,9\%) and Netherlands (6,1\%).

Table 2. The share of people at risk of poverty and social exclusion in 2015 (\% of population) - Central and Eastern Europe, Germany and Netherlands

\begin{tabular}{|l|l|l|l|l|}
\hline & \multicolumn{1}{|c|}{ Total } & Children (0-17) & Adults (18-64) & $\begin{array}{c}\text { Elderly } \\
\text { (65 years and over) }\end{array}$ \\
\hline EU-28 & 23.7 & 26.9 & 24.7 & 17.4 \\
\hline Bulgaria & 41.3 & 43.7 & 37.4 & 51.8 \\
\hline Czech Republic & 14 & 18.5 & 13.6 & 10.9 \\
\hline Croatia & 29.1 & 28.2 & 28.5 & 31.9 \\
\hline Hungary & 28.2 & 36.1 & 28.9 & 17.1 \\
\hline Poland & 23.4 & 26.6 & 24.1 & 17.0 \\
\hline Romania & 37.4 & 46.8 & 35.7 & 33.3 \\
\hline Slovenia & 19.2 & 16.6 & 19.7 & 20.2 \\
\hline Slovakia & 18.4 & 24.9 & 17.8 & 12.8 \\
\hline Germany & 20 & 18.5 & 21.3 & 17.2 \\
\hline Netherlands & 16.4 & 16.8 & 19.1 & 6.1 \\
\hline
\end{tabular}


Figure 2 displays that in 2016, the at-risk-of-poverty rate had as an EU average $17,3 \%$ and it encountered the highest value in Romania (25,3\%). Observing the situation at the level of Central and Eastern Europe, we may say that Bulgaria was the next country with a high score on poverty $(22,9 \%)$, while the other CEE countries were ranked as follows: Croatia (19,5\%), Poland (17,3\%), Slovenia (13,9\%), Slovakia $(12,7 \%)$. Croatia underwent a similar situation as in 2015, having the smallest percentage of people at risk of poverty $(9,7 \%)$ both at the level of CEE as well as at the one of the entire European Union. On the other hand, Germany and Netherlands, which are countries with well-developed economic and social systems did not succeed in obtaining very low scores, thus Germany recorded $16,5 \%$ and Netherlands scored 12,7\%.

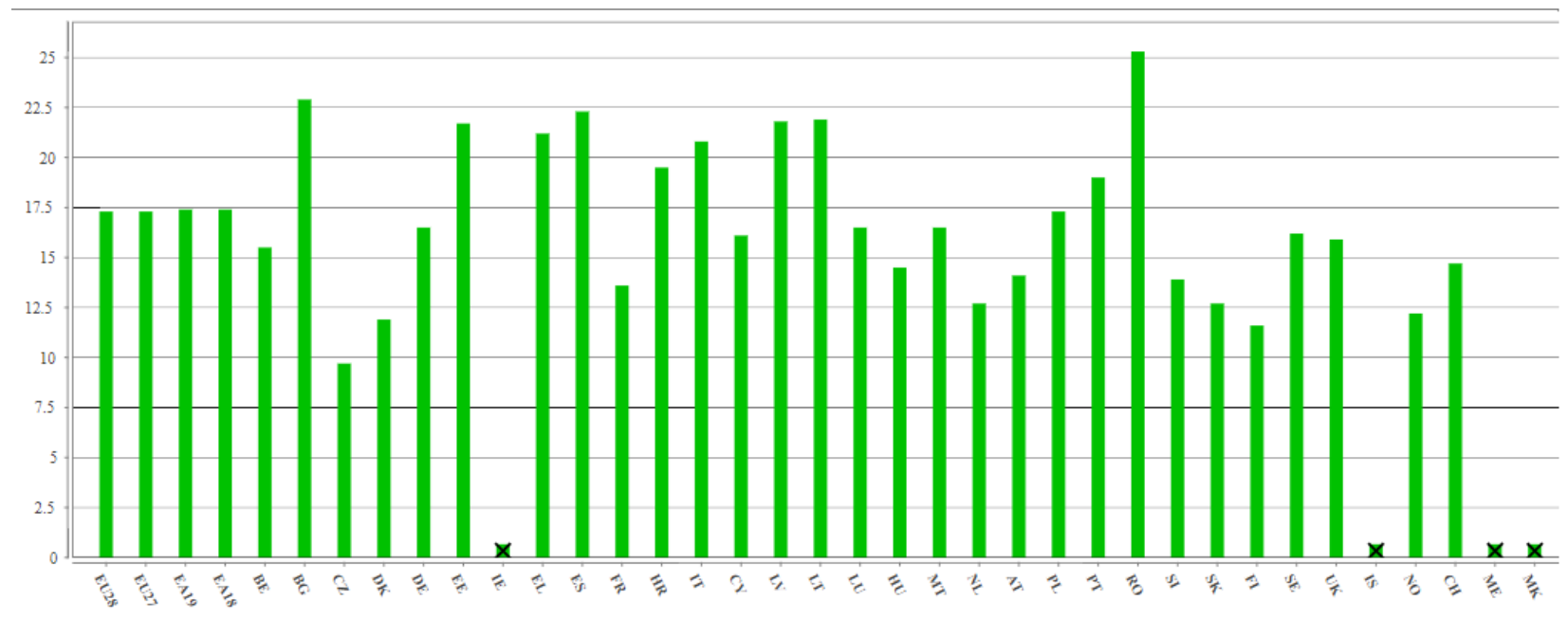

Figure 2. At risk of poverty rate (\%) - year 2016

Source: Eurostat, 2016c.

With reference to the evolution of poverty and social exclusion at the level of the European Union, Eurostat (2017c) states that the number of persons at risk of poverty and social exclusion experienced a descending tendency in 2016, thus it was of 117,5 million people $(23,4 \%)$. In addition, Eurostat specifies that the individuals who contributed to forming this number could be found in one of the following situations: monetary poverty, their income being under the at-risk-of-poverty limit as established by each state, acute material deprivation (inability of accessing resources for living) or belonging to households in which the adult members don't work up to their entire work capability, but to less than $20 \%$ from it.

Eurostat also argues that the at-risk-of-poverty rate is not a realistic indicator for poverty, because it is closely correlated with the national income standard (threshold) set by each EU country.

In what regards the second approach of poverty, the material deprivation, it can be displayed by assessing the Social Progress Index, an indicator which incorporates multiple social dimensions to render the countries' social performance. More precisely, according to Porter et al. (2017), the index was developed by Social Progress Imperative in association with the European Commission to undertake the development strategy in the period 2014- 
2020. Concerning its structure, the Social Progress Index follows 3 dimensions, computed through an averaging approach of their sub-components: basic human needs, foundations of wellbeing and opportunity, as per Stern et al. (2017).

Furthermore, after establishing the overall social progress score, the countries are ranked in several categories, the extreme points being "Very High" and "Very Low". As intermediary categories, the following are involved in the classification process: "High", PICBE | 88 "Upper Middle", "Lower Middle" and "Low."

The dimensions which are relevant for our analysis are: basic human needs (nutrition, water, shelter), foundations of wellbeing (access to basic knowledge, health and wellness), opportunity (personal rights, tolerance and inclusion) as they best suit the poverty definitions and approaches presented in the literature review section.

Regarding the social progress for year 2014, Figure 3, constructed based on data from Porter et al. (2014) and Porter et al. (2015), highlights that at the level of Central and Eastern Europe, the countries having "high social progress" were Slovenia $(81,65)$, followed by Czech Republic $(80,41)$. At the opposite point there could be identified Bulgaria and Romania, with scores of 70,24 and 67,72, respectively ("lower middle"). At the EU level, countries with "very high social progress" were Switzerland $(88,19)$, Netherlands $(87,37)$, Norway $(87,12)$, Sweden $(87,08)$, Finland $(86,91)$ and Denmark $(86,55)$. In 2015, the situation did not change too much in CEE, since the countries were ranked in the same order as in 2014, while the scores increased to a very small extent.

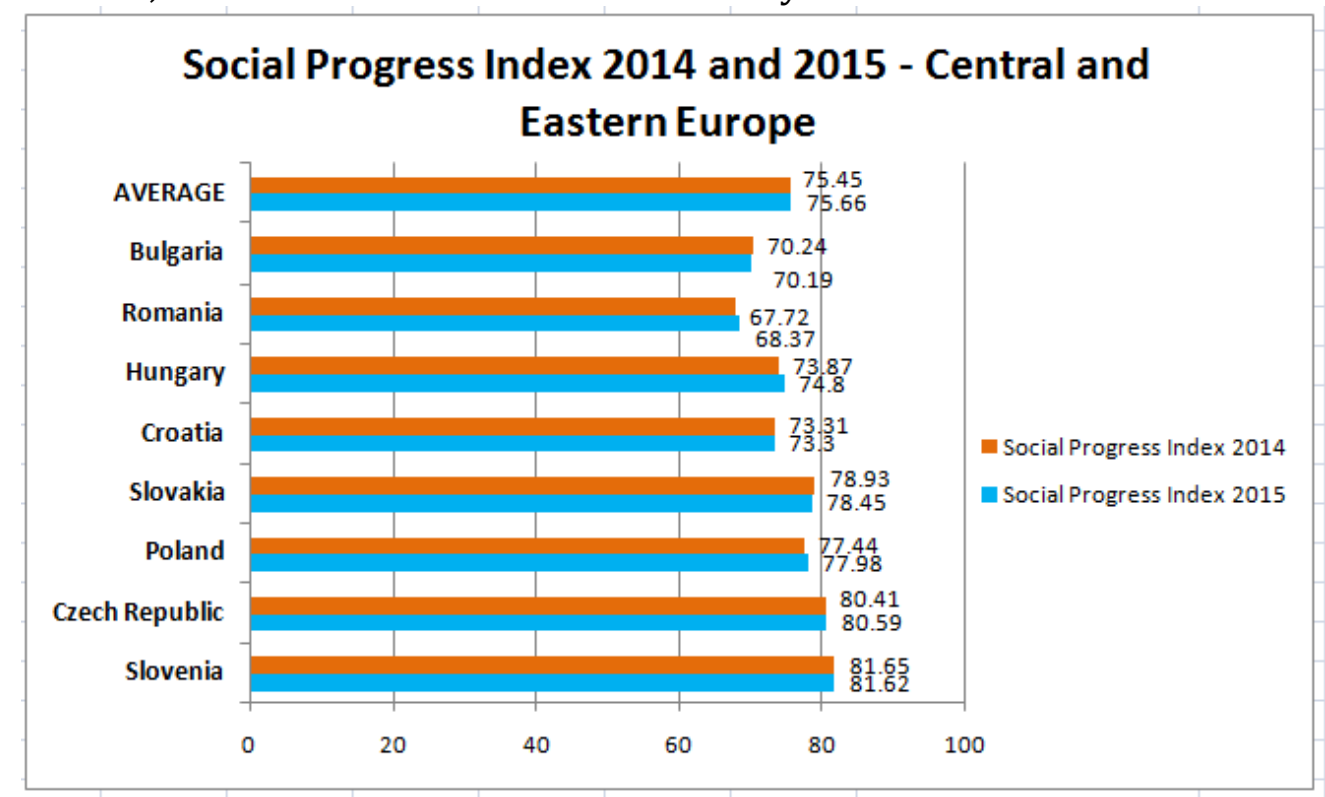

Figure 3. Social Progress Index 2014 and 2015 in Central and Eastern Europe

Source: author's own graphical representation based on Porter et al.(2014) and Porter et al. (2015).

Based on Figure 4 we may notice that in 2016 and 2017 the social progress scores have increased at the level of CEE and the countries' positioning was very similar compared to the previous years, whereas the regional yearly average score followed an ascending 
trend, from 75,45 in 2014 and 75,66 in 2015, to 78,09 in 2016 and 78,97 in 2017, thus people's life quality has improved in the period of analysis.

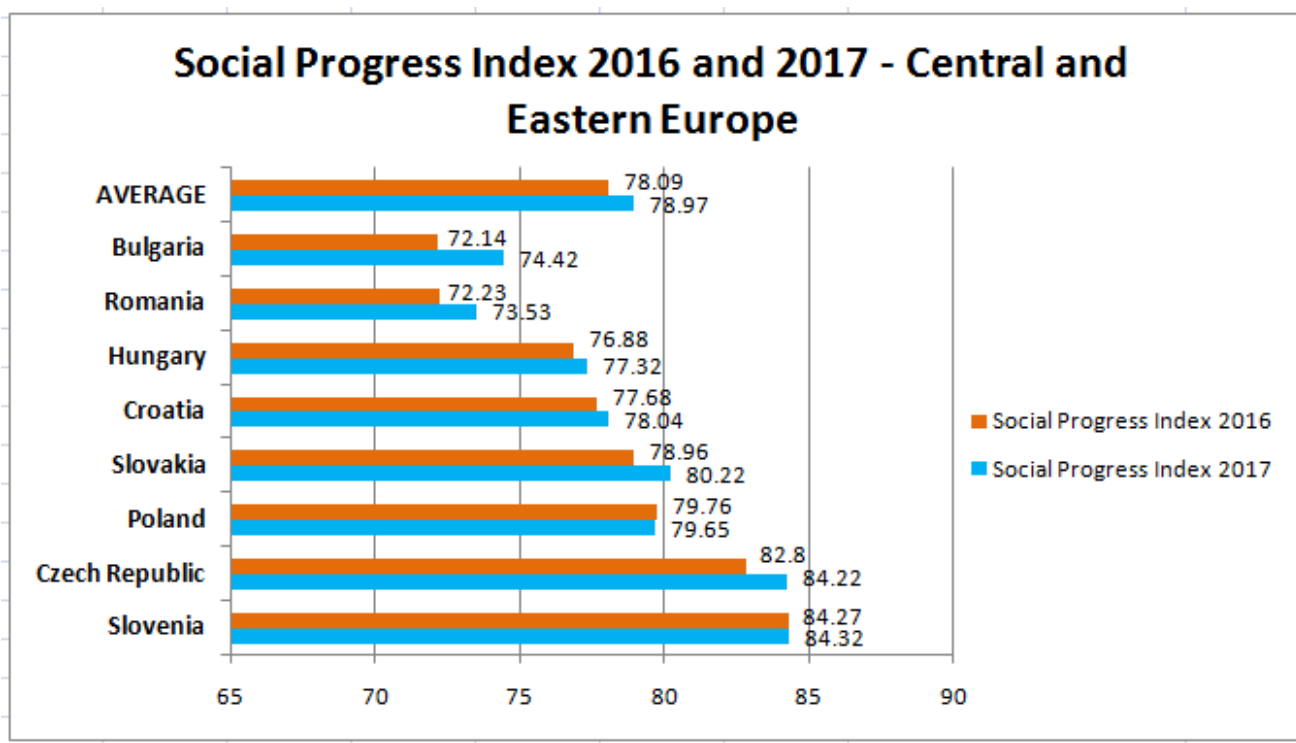

Figure 4. Social Progress Index 2016 and 2017 in Central and Eastern Europe

PICBE | 89

based on Porter et al. (2016) and Porter et al (2017)

When assessing Romania's performance in 2017 by dimensions, compared to the first ranked (Slovenia), it may be observed from Figures 5 and 6 that there are consistent dissimilarities for the dimensions (basic human needs, foundations of wellbeing, opportunity) and sub-dimensions of interest (nutrition and basic medical care, water and sanitation, access to basic knowledge, health and wellness, tolerance and inclusion). Romania had the poorest score on opportunity, while its associated sub dimension, tolerance and inclusion, had a modest value of 39.43, well below Slovenia's situation $(63,76)$. These values prove that Romania must develop and implement adequate social inclusion policies to minimize the impact of this issue on human wellbeing and to give its inhabitants equal living chances. On the other hand, Romania performed well on ensuring decent basic human needs, as its score was not far from what Slovenia registered, the same being true for the foundations of wellbeing dimension. Thus, no major improvements need to be made regarding these two progress elements. 


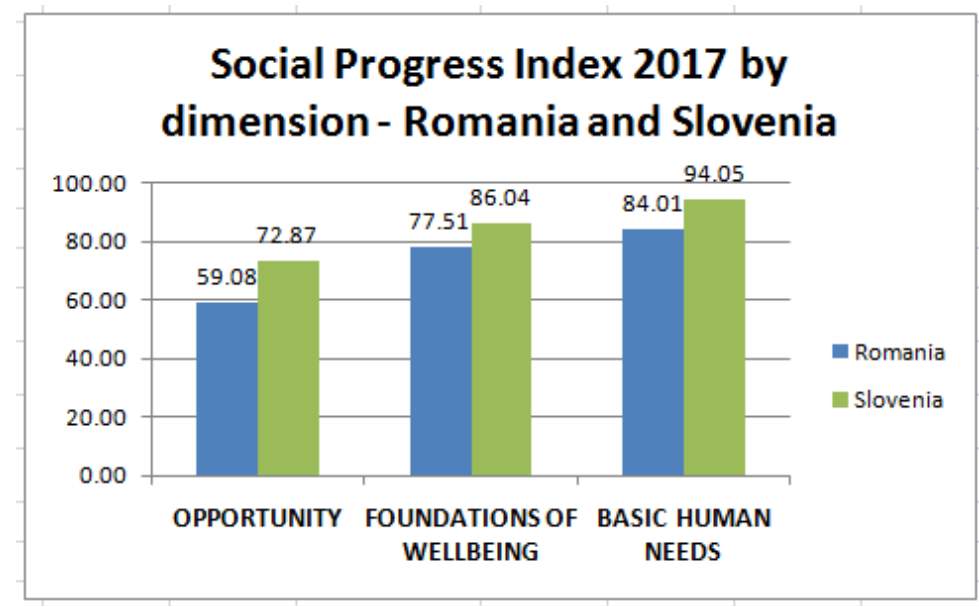

PICBE $\mid 90$

Figure 5. Social Progress Index 2017 by dimension - Romania and Slovenia

Source: author's own graphical representation based on Social Progress Index 2017a and Social Progress Index 2017b.

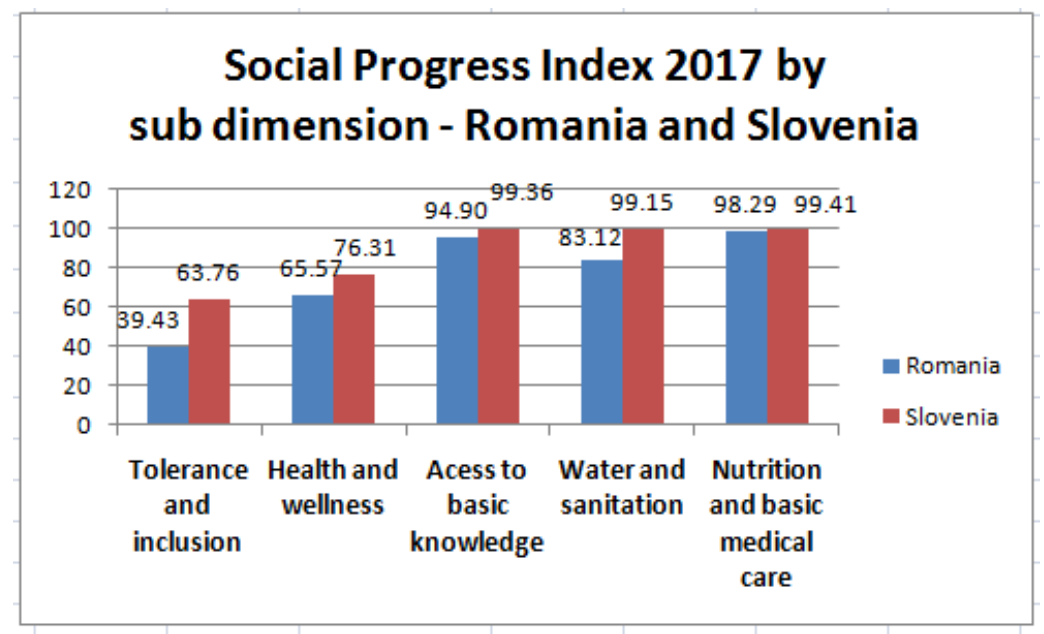

Figure 6. Social Progress Index 2017 by sub dimension - Romania and Slovenia

Source: author's own graphical representation based on Social Progress Index 2017a and Social Progress Index 2017b.

\section{Conclusion}

The paper has outlined theoretical and methodological elements regarding the evolution of poverty, social exclusion, social progress and their corresponding indicators (real GDP growth, at risk of poverty rate, Social Progress Index) for Central and Eastern European countries in the period 2014-2017. Starting from the statistical findings, we notice intraregional disparities in the analyzed countries' social performance, which generates the need for creating more coherent social policies at the level of CEE. However, one research limitation could reside in the relatively short period of time based on which the assessment was concluded, making it difficult to investigate the entire complexity of the issue. Furthermore, the findings can be of interest for social policymakers, who may develop innovative social strategies by building on the paper's outcomes. 


\section{References}

Akindola, R.B. (2009). Towards a definition of poverty. Journal of Developing Societies, 25(2), 121-150.

Bodea, G., \& Herman, E. (2014). A world of poverty?. Procedia Economics and Finance, 15, 643-653.

Cantaragiu, R., Paunescu, C., \& Hadad, S. (2014). The social impact of university

PICBE | 91 entrepreneurship in Romania: Is the institutional discourse replicated or adapted?. Management \& Marketing, 9(4), 403-422.

Copus, A., Melo, P. C., Kaup, S., Tagai, G., \& Artelaris, P. (2015). Regional poverty mapping in Europe - Challenges, advances, benefits and limitations. Local Economy, 30(7), 742764.

Eurostat (2016a). People at risk of poverty or social exclusion. Retrieved from http://ec.europa.eu/eurostat/statistics-explained/index.php/ People_at_risk_of_poverty_or_social_exclusion.

Eurostat (2016b). Sustainable development in the European Union. Retrieved from http://ec.europa.eu/eurostat/en/web/products-statistical-books/-/KS-02-16-996.

Eurostat (2016c). At-risk-of-poverty rate. Retrieved from http://ec.europa.eu/eurostat/ tgm/graph.do?tab=graph\&plugin=1\&pcode=tespm010\&language=en\&toolbox=data.

Eurostat (2017a). Income distribution statistics. Retrieved from http://ec.europa.eu/ eurostat/statistics-explained/index.php/Income_distribution_statistics.

Eurostat (2017b). People at risk of poverty or social exclusion, by age group, 2015 (\% of specified population).png. Retrieved from http://ec.europa.eu/eurostat/statisticsexplained/index.php/File:People_at_risk_of_poverty_or_social_exclusion,_by_age_gro up,_2015_(\%25_of_specified_population).png.

Eurostat (2017c). Downward trend in the share of persons at risk of poverty or social exclusion in the EU. Retrieved from http://ec.europa.eu/eurostat/documents/ 2995521/8314163/3-16102017-BP-EN.pdf/d31fadc6-a284-47f3-ae1c$8212 \mathrm{a} 581 \mathrm{~b} 0 \mathrm{c} 1$.

Jehoel-Gijsbers, G. (2007). Explaining social exclusion; A theoretical model tested in the Netherlands. Retrieved from https://www.scp.nl/english/Publications/ Publications_by_year/Publications_2007/Explaining_Social_Exclusion.

Kastoryano, R. (2006). Europe: Space, Territory and Identity. Contemporary studies in economic and financial analysis, 88, 93-110.

Leoni, T. (2016). Social investment as a perspective on welfare state transformation in Europe. Intereconomics, 51(4), 194-200.

Madanipour, A., Shucksmith, M., \& Talbot, H. (2015). Concepts of poverty and social exclusion in Europe. Local Economy, 30(7), 721-741.

Misturelli, F., \& Heffernan, C. (2010). The concept of poverty: a synchronic perspective. Progress in Development Studies, 10(1), 35-58.

Palmer, M. (2011). Disability and poverty: A conceptual review. Journal of Disability Policy Studies, 21(4), 210-218.

Păunescu, C. (2014).Current trends in social innovation research: social capital, corporate social responsibility, impact measurement. Management and Marketing. Challenges for the Knowledge Society, 9 (2), 105-118. 
Păunescu, C., Badea, M.R. (2014). Examining the social capital content and structure in the pre-start-up planning. Procedia Economics and Finance, 15, 560-568.

Peace, R. (2001). Social exclusion: A concept in need of definition?. Social Policy Journal of New Zealand, 16, 17-36.

Porter, M.E., Stern, S., \& Green, M. (2014). Social Progress Index 2014 Executive Summary. Retrieved from http://www.socialprogressimperative.org/wpcontent/uploads/2016/06/Social-Progress-Index-2014-Executive-Summary.pdf.

Porter, M.E., Stern, S., \& Green, M. (2015). Social Progress Index 2015 Executive Summary. Retrieved from http://www.socialprogressimperative.org/wpcontent/uploads/2016/05/SPI-2015-EXEC-SUMMARY.pdf.

Porter, M.E., Stern, S., \& Green, M. (2016). Social Progress Index 2016 Executive Summary. Retrieved from http://www.socialprogressimperative.org/wpcontent/uploads/2016/06/2016-Social-Progress-Index-Executive-Summary.pdf.

Porter, M.E., Stern, S., \& Green, M. (2017). Social Progress Index 2017. Retrieved from https://www.socialprogressindex.com/assets/downloads/resources/en/English2017-Social-Progress-Index-Findings-Report_embargo-d-until-June-21-2017.pdf.

Püss, T., Viies, M., \& Maldre, R. (2010). EU-12 countries in the context of European Social Model types. International Business \& Economics Research Journal, 9(12), 37-48.

Reianu, D.G., \& Nistor, A. (2017). The European pillar of social rights: Adding value to the social Europe?. Online Journal Modelling The New Europe, 22, 2-25.

Sage, D. (2013). Are more equal societies the most cohesive?. International Journal of Sociology and Social Policy, 33(11/12), 640-657.

Scharpf, F.W (2002). The European Social Model: Coping with the challenges of diversity. Journal of Common Market Studies, 40(4), 645-670.

Social Progress Index (2017a). Social Progress Summary Romania. Retrieved from https://www.socialprogressindex.com/?code=ROU.

Social Progress Index (2017b). Social Progress Summary Slovenia. Retrieved from https://www.socialprogressindex.com/?code=SVN.

Stern, S., Wares, A., \& Epner, T. (2017). Social Progress Index 2017 Methodology Report. Retrieved from http://www.socialprogressimperative.org/wpcontent/uploads/2017/06 /English-2017-Social-Progress-Index-MethodologyReport_embargo-until-June-21-2017.pdf.

Strat, V.A. and Stefan, C. (2017), "The growth poles and the lagging regions of Romania - a county level approach for 2015", Management \& Marketing. Challenges for the Knowledge Society, Vol. 12, No. 3, pp. 456-473.

Szyjko, C.T. (2011). Future of the European social model. Journal of International Relations, 9(1), 84-96.

Timofei, L. (2011). The European Social Model - pros and cons. Journal of Doctoral Research in Economics, III(4), 11-18.

World Bank (2014). Strengthening recovery in Central and Eastern Europe - EU 11 Regular Economic Report. Retrieved from http://www.worldbank.org/content/dam/ Worldbank/Feature\%20Story/ECA/eu11-regular-economic-report-july-2014.pdf. 